\title{
Internalisasi Nilai Karakter Nasionalisme melalui Dongeng dan Tari (DORI) bagi Anak Usia Dini
}

\author{
1)ENY NUR AISYAH, 2)RETNO TRI WULANDARI \\ Program Studi Pendidikan Guru Pendidikan Anak Usia Dini, Universitas Negeri Malang \\ Email: 1)eny.nur.fip@um.ac.id, 2)retno.tri.fip@um.ac.id
}

DOI: https://doi.org/10.29313/ga.v2i2.4293

\begin{abstract}
This writing aims to present a solution in learning through fairy tales and dance for early childhood education, to improving character values of nationalism character in early childhood through meaningful activities. Love of the hometown, peace of mind, caring for the environment, social care and responsibility are part of the values of the characteristics of nationalism that want to be improved through a qualitative research approach. Data collection is done by studying documentation, interviews and observing the application of DORI. to improve character values of nationalism character in early childhood education.
\end{abstract}

Keywords: Character Of Nationalism, Fairy Tales, Dance, and Early Childhood.

\begin{abstract}
Abstrak
Penulisan ini bertujuan untuk menghadirkan terobosan pembelajaran melalui dongeng dan tari pada pendidikan anak usia dini, dalam menanamkan nilai-nilai karakter karakter nasionalisme pada anak usia dini melalui kegiatan yang bermakna. Kecintaan pada tanah air, cinta damai, peduli lingkungan, peduli sosial dan tanggung jawab adalah bagian dari nilai-nilai karakteristik nasionalisme yang ingin ditanamkan melalui pendekatan penelitian kualitatif pengumpulan data dilakukan melalui studi dokumentasi, wawancara dan observasi penerapan DORI, ternyata mampu menjadi salah satu solusi untuk menanamkan nilai-nilai karakter karakter nasionalisme pada anak usia dini.
\end{abstract}

Kata Kunci: Karakter Nasionalisme, Dongeng, Tari, dan Anak Usia Dini. 


\section{Pendahuluan}

Permasalahan dunia pendidikan, saat ini cenderung menjadikan orang tua bersikap apatis terhadap perkembangan sistem pendidikan. Permasalahan kemelut kurikulum 2013 yang tidak berkesudahan, ditambah dengan maraknya sekolah-sekolah saat ini yang memberikan pelayanan dengan kurikulum asing, banyak mendapatkan tempat di hati masyarakat disbanding sekolah nasional yang terlebih dahulu ada dan berkembang. Hal ini menimbulkan beberapa keresahan akan terkikisnya rasa nasionalisme pada generasi penerus bangsa.

Berdasarkan kajian pendahuluan maraknya sekolah yang menyebut diri sebagai sekolah yang berbasis kurikulum internasional merupakan bagian dari upaya untuk meningkatkan daya jual lembaga sekolah, hingga berakibat pada melemahnya nilai nasionalisme yang dimiliki generasi penerus bangsa. Generasi saat ini cenderung memililki kesenangan dan kecintaan terhadap produk yang dihasilkan oleh negara lain dibandingkan dengan produk lokal sendiri dan tidak terlalu mengerti jati diri sebagai bangsa Indonesia serta rasa memiliki kebanggaan pada tanah air.

Kemajuan pada bidang teknologi, dan masuknya global market ke Indonesia semakin memberi peluang semakin berkurangnya rasa nasionalis yang perlu ditumbuhkan bagi generasi Indonesia. Kemajuan teknologi digital kian melekat dengan kehidupan manusia. Masyarakat yang tidak siap dalam menghadapi kemajuan teknologi, maka bisa saja kalah dengan peradaban salah satunya nasionalisme. Nasionalisme adalah bagian dari karakter yang merupakan nilai-nilai yang harus dikembangkan bagi individu yang berkebangsaan dan mencintai tanah air sejak usia dini.

Penanaman nilai-nilai karakter pada anak usia dini sangat penting dilakukan, terlebih Indonesia adalah negara yang dikenal dengan budaya ketimuran yang sangat menjunjung nilai karakter. Kementerian Pendidikan Nasional (2010) mendefinisikan pendidikan karakter sebagai pendidikan nilai, pendidikan budi pekerti, pendidikan moral, pendidikan watak yang bertujuan untuk mengembangkan kemampuan anak, untuk memberikan keputusan baik buruk, memelihara apa yang baik dan mewujudkan kebaikan tersebut sepenuh hati dalam kehidupan sehari-hari. Lewis mendefinisikan karakter sebagai seseorang yang mempunyai kualitas positif seperti peduli, adil, jujur, hormat terhaadap sesama dan bertanggungjawab. Kualitas positif tersebut disebut dengan ciri-ciri karakter, sehingga seseorang yang memiliki karakter yang baik tentu akan memiliki ciri kualitas positif [1].

Pendidikan di Indonesia, masih berupaya menuju ke arah tersebut, untuk membentuk karakter yang unggul bagi peserta didik. Khususnya Penguatan Pendidikan Karakter pada anak usia dini, saat ini semakin tidak terlihat. Banyak penyimpangan yang terjadi di sekitar lingkungan kita akibat kurangnya penanaman nilai nasionalisme bagi generasi yang sedang tumbuh saat ini. Lickona menjelaskan bahwa pendidikan karakter dimulai dengan memperkenalkan nilai karakter dan mengajak anak untuk merasakan nilai karakter dan melakukan dalam kegiatan seharihari. Karakter bukan suatu barang yang secara instan didapatkan, namun melalui perjuangan dan pembiasaan setiap hari sehingga dapat terbentuk karakter sesuai dengan yang diharapkan[2].

Sehubungan dengan hal tersebut, tentu sangat diperlukan untuk memulai pendidikan karakter sejak anak usia dini, sebab pada tahap usia dini merupakan berada pada masa golden age bagi pertumbuhan dan perkembangan anak. Jika sejak dini nilai karakter sudah distimulasi dengan baik, maka saat dewasa kelak karakter baik akan melekat pada diri anak-anak dengan kuat. Namun, pada kenyataan yang ditemukan pelaksanaan program pembelajaran di PAUD saat ini cenderung selalu mengutamakan dan memberi ruang lebih untuk anak dapat mengembangkan aspek kognitif saja. Pendidikan dinilai berhasil jika anak mampu menyelesaikan aspek akademik terkait capaian kognisi. Padahal pendidikan tidak berhenti hanya pada aspek kognitif saja. 
Kenyataan di lapangan menunjukkan bahwa nilainilai karakter yang termuat dalam, perangkat pembelajaran belum sepenuhnya terinternalisasi dalam setiap proses pembelajaran.

Persoalan kedua adalah kegiatan pembelajaran yang seharusnya berfokus pada siswa, namun justru pembelajaran berfokus pada guru/ teacher centre. Memperhatikan situasi dan kondisi yang demikian, maka diperlukan strategi belajar yang inovatif dalam menanamkan nilai-nilai karakter kepada anak di sekolah. Strategi yang dinilai tepat sesuai dengan perkembangan jaman saat ini, yaitu melalui metode dongeng dan tari (DORI). Melalui dongeng anak-anak dapat berimajinasi secara luas dan tak terbatas untuk tahu dan menanamkan nilai karakter dalam ingatan mereka, dan melalui gerakan tari yang dikolaborasikan dengan dongeng maka anak-anak secara tidak langsung belajar membiasakan untuk dapat berkarakter dengan baik.

Dongeng sebagai bagian dari sastra anak dapat digunakan untuk mengajarkan keterampilan dan praktik yang diterima anak secara luas melalui pesan moral dari setiap narasi yang diusung dalam mendongeng juga merupakan salah satu seni dan keterampilan untuk menarasikan suatu cerita dalam bentuk prosa, yang disampaikan kepada pendengarnya. Selama bertahun-tahun dongeng dapat memperkuat sikap pembaca terhadap kehidupan, terhadap hubungan manusia dan menuju moral yang baik. Tari dalam konteks pendidikan anak usia dini merupakan suatu alat atau media yang digunakan untuk mengembangkan sikap, pola pikir dan motorik anak untuk menuju kedewasaan [3]. Sehingga penggunaan metode dongeng dan tari dalam pendidikan karakter merupakan suatu upaya yang nyata untuk mencapai tujuan dari pendidikan nasional. Khususnya, ketercapaian penanaman nilai karakter karakter nasionalisme pada PAUD melalui DORI merupakan satu solusi yang harus dikembangkan dalam pelaksnaan proses belajar pada anak usia dini.

\section{Metode Penelitian}

Studi ini menggunakan pendekatan kualitatif. Studi kualitatif dilakukan untuk memperolah fakta-fakta tentang penananaman karakter karakter nasionalisme di tk laboratorium universitas negeri malang. Pengumpulan data dilakukan melalui (1) studi dokumentasi terhadap rencana pelaksanaan pembelajaran menggunakan metode dori dalam penanaman karakter karakter nasionalisme pada anak, (2) wawancara dengan beberapa guru paud di kota malang, dan (3) observasi terhadap praktik pembelajaran di beberapa kelas tk/paud di tk laboratorium universitas negeri malang. Pengumpulan data melalui berbagai cara ini dilakukan tujuannya adalah untuk "mendeskripsikan penanaman nilai karakter karakter nasionalisme pada paud melalui dori". Data kemudian dianalisis secara kualitatif dengan langkah-langkah: deskripsi, reduksi, kategorisasi dan interprestasi.

Setelah penanaman karakter karakter nasionalisme dalam pembelajaran berhasil dideskripsikan, peneliti melakukan studi literatur yang terfokus pada: tentang karakter karakter nasionalisme dan prinsip-prinsipnya, prinsip pelaksnaan metode dongeng dan tari. Studi literatur ini akan menghasilkan kerangka berfikir bagaimana menginternalisasikan karakter karakter nasionalisme melalui DORI.

\section{Pembahasan dan Hasil \\ Urgensi Membangun Nilai Karakter nasionalisme Pada Anak Usia Dini}

Pendidikan merupakan sebuah proses untuk mengangkat harkat, martabat dan kesiapan manusia dalam menghadapi masa depannya yang penuh dengan tantangan serta mengamalkan nilainilai yang selama ini terkandung dalam pendidikan. Pendidikan karakter merupakan bentuk pendidikan yang wajib dikenalkan dan ditanamkan kepada anak sejak usia dini. pendidikan jenis ini mengajarkan kepada anak untuk dapat berbuat kebajikan. Pendidikan karakter menjadi sangat penting, sebab pada saat ini banyak anak-anak yang mulai berperilaku menyimpang dan jauh dari nilai karakter terpuji.

Karakter adalah sebuah kebiasaan yang sudah terpatri dalam jiwa setiap indiidu dan sulit untuk dihilangkan. Nilai-nilai dalam pendidikan karakter perlu dikembangkan dan diajarkan sejak anak masih dini sebagai upaya agar anak-anak 
dapat membiasakan diri berperilaku yang baik dalam kehidupan sehari-hari.

Karakter sebagai poros pendidikan sesuai dengan nawacita delapan yaitu melakukan revolusi karakter bangsa. Seperti halnya filosofi pendidikan karakter Ki Hajar Dewantara yaitu olah hati (etika), olah pikir (literasi), olah karsa (estetika) dan olah raga (kinestetika). Nilai-nilai karakter yang perlu untuk dikembangka adalah 1) religius yaitu sikap dan perilaku yang patuh dalam melaksanakan ajaran agama yang dianutnya, bersikap toleean terhadap pelaksanaan ibadah lain dan hidup rukun dengan pemeluk agama yang berbeda, 2) nasionalis yaitu cara berpikir, bertindak dan berbuat yang menunjukkan kesetiaan, kepedulian, dan penghargaan yang tinggi terhadap bahasa, lingkungan fisik, sosial dan budaya serta ekonomi dan politik bangsa, 3) mandiri yaitu sikap yang tidak mudah bergantung pda orang lain dalam hal menyelesaikan tugas, 4) gotong royong yaitu bekerja bersama-sama dalam mencapai suatu hasil yang didampakan dapat melalui musyawarah, dan kekeluargaan, dan 5) integritas yaitu upaya yang menjadikan dirinya sebagai orang yang selalu dapat dipercaya dalam perkataan, tindakan dan pekerjaan[4].

Berlangsungnya revolusi digital dimana saat ini akses informasi dari berbagai belahan dunia dapat diakses dengan sangat mudah menjadi bomerang tersendiri bagi anak usia dini yang belum dapat mengimbangi dan menyaring setiap informasi yang masuk. Era digital saat ini membawa perubahan yang luar biasa pada setiap lapisan kehidupan sehingga manusia pada saat ini lebih tergantung pada teknologi. Perubahan peradaban masyarakat dari yang dulu hingga saat ini turut mewarnai tergesernya karakter pada generasi yang ada saat ini. Maraknya sekolah yang mengimplementasikan kurikulum internasional tanpa disadari mengikis karakter nasionalisme pada anak usia dini. sistem pendidikan internasional yang saat ini banyak dijumpai pada lembaga pendidikan cenderung dinilai lebih baik oleh sebagian masyarakat Indonesia. Padahal pada kenyataannya, sistem pendidikan nasional indonesia sendiri lebih mengutamakan pendidikan karakter pada proses pembelajarannya.
Pembentukan karakter bangsa sejak usia dini maka salah satu aspek yang dikembangkan adalah pendidikan nilai. Apabila anak diberikan pendidikan nilai sejak dini, maka diharapkan pada perkembangan selanjutnya anak akan mampu membedakan baik dan buruk, benar dan salah. Salah satu bidang yang harus ada dalam pendidikan nilai moral adaah nasionalisme. Di era globalisasi saat ini wawasan kebangsaan menjadi sangat penting untuk diberikan kepada anak usia dini. melalui pendidikan wawasan kebangsaan diharapkan anak-anak akan tumbuh menjadi generasi yang mencintai negeri dan tanah airnya. Sebaliknya, apabila pendidikan wawasan kebangsaan tidak diberikan kepada anak sejak dini, maka nilai kebangsaan mereka tidak akan kuat.

Grand desain pendidikan karakter (Kemendiknas, 2010), pendidikan karakter merupakan proses pembudayaan dan pemberdayaan nilai-nilai luhur dalam lingkungan satuan pendidikan, lingkungan sekolah, dan lingkungan masyarakat. Menanamkan nilai karakter nasionalisme pada anak usia dini tidak dapat dilakukan seperti mentrasfer ilmu pengetahuan atau mengajarkan sesuatu pelajaran kepada peserta didik. Pendidikan karakter perlu dilakukan dengan bimbingan, keteladanan, pembiasaan dan pembudayaan serta ditunjang dengan iklim pendidikan yang kondusif.

Karakter nasionalismelisme pada anak usia dini perlu diajarkan dan dikenalkan, sebab karakter karakter nasionalisme menjadi ujung tombak pendidikan karakter kebangsaan yang memiliki peranan utama untuk dapat meraih kemerdekaa, mempertahankannya dan mengisinya sehingga mampu bersaing dengan bangsa lain. rasa nasionalisme ini dapat menjadi senjata yang ampuh dalam konteks kehidpan modern, terutama di tengah arus globalisasi. Rasa nasionalisme yang tinggi dan ditanamkan pada anak usia dini, maka dapat mempertahankan identitas bangsa dari gempuran asing. Nasionalisme berfungsi untuk memberikan garis yang jelas antara budaya yang mencerminkan kehidupan bangsa indonesia yang sesungguhnya dan budaya asing yang justru mengurangi rasa kebangsaan secara nasional. 


\section{Nilai Karakter Nasionalisme melalui Metode Dongeng dan Tari (DORI)}

Anak usia dini adalah manusia kecil yang memiliki potensi yang harus dikembangkan. Anak memiliki karakteristik unik yang khas dan tidak sama dengan orang dewasa. Anak cenderung selalu aktif, dinamis, dan memiliki rasa ingin tahu yang tinggi. Untuk dapat mencapai keberhasilan dalam dunia pendidikan seorang anak, maka lembaga pendidikan perlu memiliki metode yang memungkinkan anak dapat mengikuti pembelajaran dengan baik yang ditandai dengan adanya perubaham akhlak, sosial dan lq anak. Metode pembelajaran dalam upaya untuk menanamkan nilai pendidikan karakter karakter nasionalisme dapat dilakukan dengan melalui pembelajaran yang diintegrasikan antara dongeng dan tari. melalui dongeng dan tari, banyak hal yang dapat kita informasikan kepada anak-anak. Begitu juga pesan moral dan nilai-nilai agama, dapat kita tanamkan kepada anak-anak melalui tokoh-tokoh yanga da dalam dongeng tersebut.

Salah satu metode yang tepat dalam menanamkan pendidikan karakter karakter nasionalisme pada anak adalah melalui metode dongeng dan tari (DORI). Dongeng menurut Huck, Helper dan Hickman (1987) dalam Ardini diartikan sebagai "all form of narrative, written, or oral, which habe come to be handed down through the year". Diartikan bahwa dongeng adalah segala bentuk cerita yang sejak dulu sudah ada dan diceritakan secara turun-temurun[5]. Menurut Einon (2006) dalam Andini dongeng adalah berisi sekumpulan cerita yang disukai anak-anak karena memberikan kesempatan kepada anak untuk berimajinasi dengan menggambarkan peristiwaperitiwa tersebut ke dalam khayalan. Dongeng dapat menarik perhatian anak dengan mudah sehingga di serap oleh sensor memori untuk kemudian diteruskan ke memori jangka panjang [5].

Dongeng diklasifikasikan menjadi dongeng tradisional dan modern. Dongeng tradisional adalah dongeng yang bersumber dari mulut ke mulut dan diceritakan secara turun-temurun, sedangkan dongeng fantasi modern merupakan sebuah dongeng yang ceritanya bersumber dari imajinasi pengarang dan sesuai dengan keadaan pada saat cerita tersebut di buat sehingga memiliki alur cerita yang menarik. Dongeng adalah bentuk sastra lama yang bercerita tentang kejadian yang luar biasa yang penuh khayalan dan tidak benarbenar terjadi yang bersifat menghibur dan terdapat ajaran moral yang terkandung dalam cerita dongeng tersebut.

Dongeng sendiri terbagi menjadi beberapa jenis, yaitu 1) mitos yaitu dongeng yang menceritakan tentang hal-hal magis seperti cerita tentang dewa, peri atau Tuhan, 2) sage adalah jenis dongeng yang berisi cerita kepahlawanan, 3) fabel yaitu jenis dongeng yang berisi binatangbinatang yang dapat berbicara seperti manusia, 4) legenda yaitu bentuk dongeng yang menceritakan tentang asal-usul suatu bend atau tempat, 5) cerita lucu atau disebut dengan cerita jenaka adalah jenis dongeng yang berkembang di masyarakat dan dapat membangkitkan tawa, 6) cerita pelipur lara yaitu jenis dongeng yang berbentuk narasi yang bertujuan untuk menghibur tamu pada suatu pesta yang dibawakan oleh seorang yang ahli, dan 7) perumpamaan yaitu jenis dongeng yang mengandung kiasan.

Dongeng termasuk salah satu bentuk cerita rakyat dimana cerita tersebut banyak mengandung nilai karakter yang terpuji. Dongeng dapat dimanfaatkan sebagai upaya untuk mengasah emosi, menumbuhkan imajinasi serta meningkatkan daya kritis anak. Pada umumnya dongeng memiliki misi positif dan edukatif. Pada prinsip pengembangan dongeng bagi anak: 1) diperlukan pengembangan yang sangat menarik melalui pendekatan menyenangkan yang berbasis pada minat anak, 2) Tema-tema yang menambah kecintaan kepada tanah air, dan timbulnya rasa bangga kepada bangsa harus dimunculkan, 3) Pengemasan narasi dongeng yang unik dan penyampaian dongeng yang menarik, 4) bermuatan pesan moral untuk cinta tanah air yang mudah dipahami anak, dan 5) Narasi dongeng tidak terlalu panjang dan mudah dipahami oleh anak.

Keterampilan pendongeng dalam menyampaikan dongeng yang baik setidaknya diperlukan: 1) kemampuan mengelola ekspresi emosi dengan baik, 2) mampu membaca minat pendengar cerita, 3) mampu untuk mengajak 
pendengar menikmati suasana dongeng, 4) mampu menyudahi dongeng dengan muatan pesan yang sesuai tujuan, dan 5) mampu mengelola waktu mendongengn dengan baik[9]. Berbeda dengan dongeng, pembelajaran tari memiliki peranan dalam pembentukan pribadi atau mental yang selaras pada anak usia dini. tari memfokuskan pada pemenuhan kebutuhan perkembangan emosional dan kecerdasan sosial yang baik, selain juga kemampuan motorik anak. Semakin maraknya budaya asing yang masuk, seperti bahasa, tari dan pakaian merupakan sebuah ancaman yang besar bagi integritas suatu negara. Permasalahan yang muncul nantinya adalah eksistensi nilai, moral dan karakter bangsa Indonesia.

Indonesia memiliki keanekaragaman tari. Setiap daerah memiliki tarian yang khas, yang menjadi ciri khas dari daerah tersebut. Banyaknya ragam tari di Indonesia mencerminkan keanekaragaman budaya bangsa ini. Pendekatana pembelajaran tari yang berorientasi pada siswa di sekolah pada dasarnya mengacu pada prinsip perkembangan anak dimana salah satunya siswa belajar dengan baik apabila kebutuhan fisik dan psikologis terpenuhi dengan baik. Melalui gerakan tari, koreografi pada anak usia dini bertujuan untuk mengembangkan seluruh aspek perkembangan anak selain juga fisik motorik mereka. Dongeng dan tari yang dikolaborasi menjadi sebuah metode pembelajaran yang menarik bagi anak, dimana anak dapat berimajinasi sekaligus mempraktekkan secara langsung merupakan kemenarikan tersendiri dalam proses pembelajaran bagi mereka. Tarian bagi anak diajarkan untuk memberikan bimbingan kepada anak dalam berbagai variasi kegiatan fisik dan memperkenalkan secara sadar melalui fungsi dan hubungan anggota tubuh mereka. Berlatih keterampilan dalam kesimbangan gerak sesuai ritmik nada yang bersinergi dengan kelenturan otot.

Inovasi dan kemampuan guru dalam menghadirkan terobosan strategi terbaru untuk menanamkan nilai karakter kebangsaan kepada anak perlu dikemas dengan cara yang menarik dan tidak biasa. Jika pada pembelajaran terbiasa dengan berfokus pada guru, maka pembelajaran dapat diubah dengan berfokus pada anak didik. Anak usia dini dapat belajar dengan baik dengan cara membangun pengalamannya sendiri, sehingga melalui dongeng anak dapat berimajinasi secara luas dan melalui tari anak dapat mempraktekkan apa yang sudah diimajinasikan oleh anak.

Terdapat banyak manfaat yang dapat diambil melalui pembelajaran yang menggunakan dongeng dan tari, antara lain: 1) dapat mengembangkan imajinasi anak, 2) menambah pengalaman yang nyata kepada anak, 3) melatih daya konsentrasi anak, 4) menambah perbendaharaan kata, 5) mengembangkan emosi anak, 6) melatih daya tangkap dan 7) mengenal nilai-nilai positif dan negatif [6]. Berdasarkan hal tersebut pembelajaran melalui dongeng dan tari anak sebagai upaya untuk menanamkan nilai karakter nasionalisme pada anak usia dini dinilai sebagai perpaduan yang pas. Anak-anak dapat berimajinasi secara luas sekaligus mempraktekkan secara langsung melalui gerakan tari yang disesuaikan dengan cerita tersebut.

\section{Capaian Hasil Implementasi Karakter nasionalime melalui DORI}

Perkembangan teknologi yang membawa perubahan pada dunia pendidikan mampu mengubah sistem pendidikan yang sudah berkembang di Indonesia. Pada saat ini semua informasi dapat diakses dengan sangat mudah dan cepat sehingga masyarakat tidak lagi kesulitan dalam mencari dan menerima informasi. Dampaknya, dunia pendidikan saat ini dikuasai oleh banyak teknologi. Kemajuan ilmu pengetahuan dan teknologi yang disertai dengan semakin kencangnya arus globalisasi dunia membawa dampak yang luar biasa dalam dunia pendidikan. Saat ini, banyak sekolah di Indonesia dalam beberapa tahun terakhir mulai melakukan globalisasi di bidang sistem pendidikan. Hal ini terlihat dari diterapkannya bahasa asing dalam sekolah, dan mulai mengadopsi kurikulum internasional. Selain itu, berbagai jenjang pendidikan di Indonesia sudah mulai membuka program kelas internasional.

Kemajuan sistem pendidikan tersebut sebagai upaya yang dilakukan pada bidang 
pendidikan untuk meningkatkan kualitas pendidikan Indonesia, namun pada kenyataannya ketidaksiapan guru dalam menyampaikan materi yang sesuai cenderung membuat peserta didik menjadi salah dalam menyikapi kemajuan. Perkembangan dunia pendidikan di Indonesia tidak dapat dilepaskan dari pengaruh globalisasi. Era pasar bebas yang memungkinkan masuknya tenaga pendidik dari mancanegara membuat pendidikan di Indonesia harus dapat lebih ditingkatkan lagi kualitasnya.

Perkembangan ilmu pengetahuan dan teknologi tersebut selain membawa dampak positif, juga membawa dampak negatif. Salah satu dampak negatif yang muncul adalah semakin mengikis rasa nasionalis pada diri generasi muda saat ini. Banyak diantara masyarakat saat ini lebih menyukai produk asing dibandingkan dalam negeri. Selain itu, wawasan kebangsaan anak usia dini saat ini juga mulai luntur. Pendidikan karakter yang seyogyanya adalah pendidikan yang sangat penting bagi tumbuh kembang anak untuk mengahdapi dunianya saat dewasa kelak, perlu digalakkan lagi. Pendidikan karakter bertujuan agar menjadikan seseorang memiliki karakter yang baik [7] Proses pendidikan merupakan bagian dalam menyiapkan karakter yang baik bagi anak.

$$
\text { Upaya dalam mengintegrasikan }
$$

pendidikan karakter dengan kegiatan pembelajaran di kelas dapat melalui kegiatan belajar mengajar yang diintegrasikan pada kegiatan atau mata pelajaran tertentu. Menanamkan nilai karakter nasionalisme pada anak usia dini, bukan sebuah perkara yang mudah. Nilai karakter nasionalisme tidak dapat sekedar diajarkan, melainkan melalui pemahaman yang mendalam dan pembiasaan yang dilakukan secara terus menerus ${ }^{[8]}$.

Dongeng yang dibacakan oleh guru dan didengarkan oleh anak maka tanpa disadari pesan moral yang terkandung dalam dongeng tersebut akan tertanam dengan kuat dalam benak setiap anak. Sehingga, pesan nilai nasionalisme yang hendak disampaikan dapat tercapai. Begitu pun demikian dengan tarian, melalui gerakan tari anak dapat belajar mengimplementasikan nilai-nilai yang terkandung dalam tarian tersebut. Selain itu, strategi belajar melalui dongeng dan tari merupakan cara yang menarik bagi anak-anak, sehingga anak-anak akan menyukai kegiatan belajar ini karena melibatkan aktivitas fisik yang mengajak mereka bergerak secara variatif dan memainkan emosi sosialnya dalam suatu aktivitas yang menyenangkan.

Kecintaan pada tanah air, cinta damai, peduli lingkungan, peduli sosial dan tanggung jawab dapat menjadi prioritas capaian karakter nasionalisme selama proses mengajar. Cerita tetang persahabatan ikan di bawah laut, penyelamatan habitat laut dari pemburu liar dan juga pembuangan limbah menjadi sesuatu yang sangat dinantikan anak pada tema Lautku indonesiaku. Penyampaian dongeng maupun tari berbasis tema yang sedang dilaksnakan selama peroses belajar menjadi sesuatu yang sangat dinantikan dan digemari anak karena masingmasing anak selama proses belajar harus turt serta berperan aktif untuk menjadi salah satu tokoh yang memaikan gerakan sesuai ritmik irama lagu.

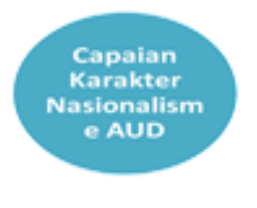

Metode Tari

\section{Gambar. Capaian Karakter Nasionalisme di PAUD}

Keterlibatan peran aktif siswa dalam menyampaikan cerita dan juga menggerakan organ motoriknya menjadikan internalisasi karakter nasionalisme sangat berkesan dan menarik untuk dihadirkan dalam beberapa aktivitas di sentra main peran dengan tema yang beragam sesuai program 
tahun ajaran sekolah yang disepakati. Learner centre dalam aktivitas mendongeng tidak hanya melibatkan satu penyaji namun juga harus berupaya menghadirkan kemampuan penyaji dongeng baru dari anak-anak selama interaksi berlangsung. Keberhasilan dan kemenarikan dalam penanaman karakter nasionalisme menjadi satu solusi cerdas dalam penananaman karakter nasionalisme khususnya dan karakter-karakter yang lain pada umumnya.

Pembelajaran yang dikemas dengan menarik dan melibatkan anak untuk aktif sepenuhnya menjadi pembelajaran lebih bermakna[10]. Sehingga, apa yang dipelajari oleh anak di masa kecil akan tetap terkenang dan terbawa menjadi kebiasaan sampai dewasa kelak. Salah satu strategi yang dapat dilakukan oleh pendidik PAUD dalam mengajarkan nilai karakter nasionalisme adalah melalui dongeng dan tari dengan optimalisasi peran fasilitator guru yang mumpuni, yakni sebagai catalyst, resources linker, process helper dan solution giver/helper [11].

\section{Kesimpulan}

Berlangsungnya revolusi digital dan maraknya sekolah yang menganut sistem pendidikan asing membuat beberapa nilai karakter yang mestinya diajarkan pada pendidikan anak usia dini menjadi kurang terpenuhi. Masyarakat cenderung mengabaikan nilai karakter karakter nasionalisme yang seharusnya dimiliki anak sejak usia dini, dengan dalih lebih menyukai budaya asing yang masuk ke dalam negeri. Akibatnya wawasan kebangsaan semakin terkikis.

Anak usia dini sebagai generasi penerus bangsa, melalui pendidikan yang diintegrasikan dengan disesuaikan pada kebutuhan dan tingkat perkembangan anak harus dapat memunculkan nilai-nilai karakter karakter nasionalisme. Guru sebagai pendidik, diyakini harus memiliki kemampuan berinovasi membuat terobosan baru dalam sistem pembelajaran dengan salah satunya menggunakan metode belajar DORI.

Nilai karakter nasionalisme tidak dapat sekedar diajarkan, melainkan melalui pemahaman yang mendalam dan pembiasaan yang dilakukan secara terus menerus. Capaiaan keberhasilan dalam menanamkan karakter nasionalisme tidak lepas dari peran aktif guru sebagai seorang fasilitator dan juga mediator yang berperan aktif selama proses belajar. Kesesuaian tema dalam aktvitas proses belajar yang dikembangkan berdasarkan minat dan keunikan masing-masing anak melalui capaian keberhasilan yang Nampak pada karakter nasionalisme yang diharapkan mnejadi tolak ukur kebermakanaan proses internalisasi nilai karakter nasionalis yang diharapkan.

Kemauan untuk berinovasi, merubah target dan capaian menjadi suatu hasil yang lebih maksimal serta berani menerima tantangan dalam pelaksanaan proses belajar peserta didik harus menjadi kemaun setiap guru guna meningkatkan kulitas belajar. Kebermaknaan belajar dapat dihadirkan melalui sinergi keberhasilan guru mengelola proses belajar, kemauan murid dalam belajar dan terpenuhinya kebutuhan belajar yang sesuai tujuan belajar.

\section{Daftar Pustaka}

Andini, Pupung Puspa. 2012. Pengaruh Dongeng dan Komunikasi Terhadap Perkembangan Moral Anak Usia 7-8 Tahun. (1) (1). Gontalo: FIP UNG

Dewantoro, Ki Hadjar, 1933. Pendidikan Adab (dalam Buku I: Pendidikan). Yogyakarta: Taman Siswa.

Habsari, Zakia. 2017. Dongeng Sebagai Pembentuk Karakter Anak. Malang: Universitas Negeri Malang. (Online)

Hardika. 2012. Pembelajaran Transformastif Berbasis Learning How to Learn Teori, Model dan Implementasi dalam Pembelajaran. Malang: UMM Pers

Kemendikbud. 2017. Modul Pelatihan Penguatan Pendidikan Karakter bagi Guru. Jakarta: Pusat Analisis dan Sinkronisasi Kebijakan Sekretariat Jenderal Kementrian Pendidikan dan Kebudayaan

Lewis, Barbara A. 2004. Character Building Untuk Anak Usia Dini. Batam: Karisma Publising Group

Lickona, Thomas, 1992. Educating for Character, New York: Bantam Books

Mursid, 2009. Belajar dan Pembelajaran PAUD. Bandung: PT Remaja Rosdakarya 
Nuryanto, Sidik \& Rita Eka Izzaty. 2016. Peranan Dongeng Dalam Pendidikan Karakter Pada Taman Kanak-Kanak Lazuardi Kamila Di Surakarta. Yogyakarta: UNY. (Online)

Sa'dun, Akbar dkk. 2015. Pendidikan Karakter Best Practices. Malang: Universitas Negeri Malang

Wulandari, Retno Tri. 2015. Pengetahuan Koreografi Untuk Anak Usia Dini. Malang: FIP UM 